\title{
Direct Spectrophotometric Determination of Ni (II) Using 5- Bromo-2- hydroxyl -3-methoxybenzaldehyde-4-hydroxy benzoichydrazone
}

\author{
B.Saritha and Prof. T.Sreenivasulu Reddy* \\ Department of Chemistry, Sri Krishnadevaraya University, Anantapur 515003 (A.P), India
}

\begin{abstract}
A rapid, simple,sensitive and selective direct spectrophotometric method has been developed for the determination of nickel(II) in various real samples. 5-Bromo-2-hydroxy-3-methoxy benzaldehyde-p-hydroxybenzoic hydrazone reacts with $\mathrm{Ni}(I I)$ forming green coloured soluble complex [ ( Ni(II)-5-BHMBHBH] in basic buffer solution. The maximum absorbance was observed in the pH range 5.5-7.5 and Ni(II)-5-BHMBHBH shows at $\lambda_{\max }$ at $440 \mathrm{~nm}$. The method obeys Beer's law in the range 0.117 to $2.64 \mu \mathrm{g} / \mathrm{ml}$. The molar absorptivity is $2.013 \times 10^{4} \mathrm{~L} \mathrm{~mol}^{-1} \mathrm{~cm}^{-1}$ and Sandell's sensitivity is $0.0029 \mathrm{mg} / \mathrm{cm}^{2}$. The standard deviation of the method for ten determinations of $0.6050 \mu \mathrm{g} / \mathrm{ml}$ of $\mathrm{Ni}(\mathrm{II})$ is 0.00256 . The correlation coefficient ( $\gamma)$ of the calibration equation of the experimental data is 0.9999. The effect of various diverse ions is studied. The formula of the complex is 1:1 and its stability constant is $2.83 \times 10^{6}$. The method developed has been used for the determination of nickel(II) in alloy samples, drinking water, plant samples and in vegetable oil.
\end{abstract}

Keywords: Ni(II), Spectrophotometry, 5-Bromo-2-hydroxy-3-methoxy benzaldehyde-p-hydroxybenzoic hydrazine (5-BHMBHBH).

\section{Introduction:}

Although nickel complexes in +3 oxidation state are known, it usually occurs in +2 state. It is one of the important alloying element for steel and cast iron. These alloys are used in ship building, jet turbines, magnets, heating elements, electrodes, electronic, electroplating, inks, varnishes, pigments and ceramics. Because of its permanence in air and its innerness to oxidation, it is used in coins, for plating iron, brass, etc. It is equally important as a catalyst in the hydrogenation of oils. The possibility that nickel may be an essential micro nutrient ${ }^{1-3}$ for plants arose from ureases which is a nickel metalloenzyme. Nickel is biologically important, being an essential trace element in human diet. Nickel bound to ribonucleic acid, has a special affinity for bone and skin and plays an important role in pigmentation. It has been reported that normal human plasma contains $0.012-0.085 \mathrm{ppm}$ of nickel (II). Nickel is abundant in lithosphere and biosphere so that natural deficiency does not occur. This may be the reason why nickel was not found to be essential for many years. Nickel is proved essential trace element for several organisms, it is an environmental carcinogen. It is very toxic to most plants and moderately toxic to mammals. A view of this there is a necessity for the development of methods for the determination of nickel (II) at micro levels.

Several instrumental techniques have been employed for the determination of nickel(II), of which UV -visible spectrophotometry is preferred because of its low cost, rapidity and easy handling.

Many classes ${ }^{4}$ of organic reagents have been described as spectrophotometric reagents for determination of nickel(II). Some reagents that were used as spectrophotometric reagents were identified ${ }^{5}$.However, some suffer from low sensitivity, interference from diverse ions or involve extraction.

Hydrazones are important class of analytical spectrophotometric reagents, the potentialities of which were review by Singh et $\mathrm{al}^{6}$. Several hydrazones ${ }^{7-9}$ were reported for the spectrophotometric determination of nickel(II) but they suffer from lack of sensitivity, interference from diverse ions or use surfactants for increasing sensitivity. Therefore, in the present paper we report a sensitive, rapid and precise visible spectrophotometric method for the determination of nickel(II) at micro levels which do not involve extraction or use surfactants.

\section{Experimental:}

The chromogenicreagent,5-bromo-2-hydroxy-3-methoxybenzaldehyde-p-hydroxy benzoic hydrazone was synthesized in the laboratory by condensing 5 - Bromo-2- hydroxy-3methoxybenzaldehyde and p-hydroxybenzoichydrazide. A 0.01M DMF solution of the reagent is used in the studies.

$0.01 \mathrm{M}$ stock solution of $\mathrm{Ni}$ (II) was prepared by dissolving requisite amount of nickel ammonium sulphate in distilled water and standardized gravimetrically ${ }^{10}$. The working solutions were prepared by 
diluting the stock solutions with distilled water.

Buffer solution of $\mathrm{pH} 6.0$ was prepared by mixing $0.2 \mathrm{M}$ sodium acetate and $0.2 \mathrm{M}$ acetic acid in suitable proportion and the $\mathrm{pH}$ was adjusted by a $\mathrm{pH}$ meter.

The absorbance and pH measurements were made on a Perkin Elmer (LAMDA 25) UV-Visible spectrophotometer (Model UV-160A) controlled by a computer fitted with $1 \mathrm{~cm}$ path length quartz cells and an ELICO digital pH meter of (Model LI 613) respectively.

\section{Procedure:}

To $5 \mathrm{ml}$ of buffer solution ( $\mathrm{pH} 6.0), 0.5 \mathrm{ml}$ of 5-BHMBHBH $\left(1 \times 10^{-2} \mathrm{M}\right)$ in DMF, $1.5 \mathrm{ml}$ of DMF taken in each of a set of $10 \mathrm{ml}$ volumetric flasks, varying amounts of $\mathrm{Ni}(\mathrm{II})$ were added and diluted to $10 \mathrm{ml}$ in a volumetric flask with distilled water. The absorbance of these solutions was measured at $440 \mathrm{~nm}$ against reagent blank and plotted against the mount of cobalt. A straight line is obtained which corresponded to the equation $\mathrm{A}_{440}=0.34215 \mathrm{C}+0.00051$. ( $\mathrm{C}$ is the amount of nickel in $\mu \mathrm{g} / \mathrm{ml}$ ).

\section{Results and discussions:}

The reagent 5-bromo-2-hydroxy-3-methoxy benzaldehyde-4-hydroxy benzoichydrazone (5-BHMBHBH) was used for the spectrophotometric method for determination of nickel (II). Nickel(II) reacts with 5BHMBHBH to form green coloured complex in the $\mathrm{pH}$ range 5.5-7.5. The absorption spectra of 5-BHMBHBH and its nickel (II) complex under the optimum conditions were shown in Figure1. The nickel (II)-5-BHMBHBH complex shows maximum absorbance at $440 \mathrm{~nm}$, where the reagent has negligible absorbance. The colour formation is instantaneous. It is stable for 48 hours. The analytical measurements were made at $\mathrm{pH}$ 6.0. A five fold molar excess of the reagent is sufficient to produce maximum absorbance. The formula of the complex was ascertained from jobs and molar ratio methods as $1: 1$. The stability constant of the complex is $2.83 \times 10^{6}$. The analytical characteristics of the complex are given in table-1.

\section{Effect of foreign ions:}

The effect of foreign ions and cations on the determination of $\mathrm{Ni}(\mathrm{II})$ under optimal conditions were studied table-1. The data reveals that all the anions except EDTA did not interfere in the determination of $\mathrm{Ni}(\mathrm{II})$ even in 100 fold excess. Most of the cations do not interfere in the determination even in 50 fold excess. $\mathrm{Fe}(\mathrm{III})$ and $\mathrm{Cu}$ (II), $\mathrm{Co}$ (II) were tolerated in 30 fold and 10 fold excess in presence of phosphate, thiourea and thicyanate respectively

\section{Applications:}

The present method is applied for the determination of nickel(II) in alloy samples, drinking water, vegetable oil and plant leaf samples.

\section{Preparation of alloy samples:}

$1 \mathrm{gm}$ of the alloy sample was dissolved in a mixture of $2 \mathrm{ml}$ of concentrated hydrochloric acid and $10 \mathrm{ml}$ of concentrated nitric acid. The solution was evaporated to a small volume. $5 \mathrm{ml}$ of $1: 1$ sulfuric acid was added and the solution was evaporated to dryness. The residue left over was extracted with $15 \mathrm{ml}$ of water and the solution was diluted to $100 \mathrm{ml}$ with double distilled water. This serves as the stock solution. The stock solution was appropriately diluted and analyzed by the general procedure. The results are given in table-3.

\section{Preparation of drinking water:}

The water samples were collected from different parts of Anantapur district (Andhra Pradesh, India). The water samples ( 1 liter) were collected in clean 2 liter beakers and slowly evaporated to about $25 \mathrm{ml}$. Then, $5 \mathrm{ml}$ of $\mathrm{H}_{2} \mathrm{O}_{2}$ was added and evaporated to dryness. It was then dissolved in $20 \mathrm{ml}$ of water and filtered to remove insoluble substances. The filtrate was collected in a $100 \mathrm{ml}$ volumetric flask quantitatively and diluted to the mark with distilled water.

Two untreated water samples collected from different places around anantapur town (Andhra Pradesh, India) were treated as above and have been analyzed by the general procedure. The results are presented table4.

\section{Preparation of plant samples:}

Freshly collected samples were cleaned and dried for one hour in open air protecting from mineral contamination. The dry samples were finely powdered in a mortar. The powdered material was brought in to solution by wet ashing method according to the procedures given in the literature. The suitable aliquots of the 
above sample were analyzed by the general procedure and the results are presented in table -5 .

\section{Preparation of vegetable oil:}

Hydrogenated edible groundnut $(100 \mathrm{~g})$ was dried in a hot air oven at $100^{\circ} \mathrm{C}$ and subsequently dissolved in $20 \mathrm{ml}$ mixture of 1:2:5 of $\mathrm{H}_{2} \mathrm{SO}_{4}: \mathrm{H}_{3} \mathrm{PO}_{4}: \mathrm{HNO}_{3}$. The contents were heated until sulphurous acid fumes were evolved and the volume was redused to about $5 \mathrm{ml}$. A small quantity of distilled water was added and filter paper into a $100 \mathrm{ml}$ volumetric flask and made up to the mark with distilled water.

To known aliquots of the above sample is taken in $10 \mathrm{ml}$ volumetric flasks containing $5 \mathrm{ml}$ of buffer solution, $0.5 \mathrm{ml}$ of $0.01 \mathrm{M} 5$-BHMBHBH solution and $1.5 \mathrm{ml}$ of DMF. The contents were made up to the mark with distilled water and analyzed. The results are presented in table-5.

\section{Conclusion:}

The proposed method is simple, accurate, sensitive, do not involve extraction or heating and do not use surfactants. The method can be easily applied for the determination of nickel(II) in industrial, water, oil and plant samples.

\section{Acknowledgement:}

The authors thank the department of Chemistry of S.K.University Anantapur,for providing the necessary facilities. One of authors (B.Saritha) thanks UGC for providing financial assistance under BSR scheme.

Table 1.

Analytical characteristics of [Ni(II) - 5-BНMВНВH]

\begin{tabular}{|c|l|}
\hline \multicolumn{1}{|c|}{ Parameter } & \multicolumn{1}{|c|}{ Direct method (440 nm) } \\
\hline Beer's law range $\left(\mu \mathrm{g} / \mathrm{m} \mathrm{l}^{-1}\right)$ & $0.117-2.64 \mu \mathrm{g} / \mathrm{ml}$ \\
\hline Molar absorptivity $\left(\mathrm{L} \mathrm{mol}^{-1} \mathrm{~cm}^{-1}\right)$ & $2.013 \times 10^{4} \mathrm{~L} \mathrm{~mol}^{-1} \mathrm{~cm}^{-1}$ \\
\hline Sandell's sensitivity $\left(\mu \mathrm{g} / \mathrm{c} \mathrm{m}^{2}\right)$ & $0.0029 \mu \mathrm{g} / \mathrm{c} \mathrm{m}^{2}$ \\
\hline Correlation coefficient $(\gamma)$ & 0.9999 \\
\hline Standard deviation & 0.00256 \\
\hline Y- intercept(b) & 0.00313 \\
\hline Detection limit $\left(\mu \mathrm{g} / \mathrm{m} \mathrm{l}^{-1}\right)$ & 0.016 \\
\hline Composition $(\mathrm{Metal}: \mathrm{Ligand})$ & $1: 1$ \\
\hline Stability constant(ß) & $2.83 \times 10^{6}$ \\
\hline
\end{tabular}

Table -2.

Tolerance limit of foreign ions.

\begin{tabular}{|c|c|c|c|}
\hline \multicolumn{2}{|c|}{ Amount of $\mathrm{Ni}(\mathrm{II})=1.76 \mu \mathrm{g} / \mathrm{ml}$} & \multicolumn{2}{|l|}{$\mathrm{pH}=6.0$} \\
\hline Ion & $\begin{array}{c}\text { Tolerance } \\
\text { Limit }(\mu \mathrm{g} / \mathrm{ml})\end{array}$ & Ion & $\begin{array}{c}\text { Tolerance } \\
\text { Limit }(\mu \mathrm{g} / \mathrm{ml})\end{array}$ \\
\hline Thiosulphate & 2300 & $\mathrm{Cd}$ (II) & 330 \\
\hline Ascorbate & 1300 & Mo (VI) & 10 \\
\hline Iodide & 1200 & $\mathrm{Hg}(\mathrm{II})$ & 128 \\
\hline Sulphate & 940 & $\mathrm{Zn}$ (II) & 120 \\
\hline Carbonate & 590 & $\mathrm{~Pb}$ (II) & 60 \\
\hline Chloride & 520 & Mn (II) & 66 \\
\hline Nitrate & 420 & $\mathrm{Ce}(\mathrm{IV})$ & 55 \\
\hline Bromide & 450 & $\mathrm{~V}(\mathrm{~V})$ & 52 \\
\hline Thiocyanate & 440 & $\mathrm{Se}(\mathrm{IV})$ & 36 \\
\hline Phosphate & 100 & $\mathrm{Tl}$ (III) & 33 \\
\hline EDTA & Interferes & $\mathrm{W}(\mathrm{VI})$ & 44 \\
\hline Citrate & 100 & $\mathrm{Al}$ (III) & 40 \\
\hline Tartarate & 90 & $\mathrm{Cr}$ (VI) & 10 \\
\hline Thiourea & 200 & Ti (IV) & 4 \\
\hline Oxalate & 100 & Th (IV) & 5 \\
\hline Fluoride & 190 & $\mathrm{U}(\mathrm{VI})$ & 17 \\
\hline $\mathrm{Zr}$ (IV) & 8 & $\mathrm{Fe}$ (III) & $55^{\mathrm{a}}$ \\
\hline $\mathrm{Cu}$ (II) & $17^{\mathrm{c}}$ & Co (II) & $17^{\mathrm{b}}$ \\
\hline
\end{tabular}

a:Masked with phosphate; b: Masked with thiocyanate ; c:Masked with thiourea 
Table -3.

Determination Ni (II) in Alloy samples

\begin{tabular}{|l|l|l|l|}
\hline \multirow{2}{*}{ Sample } & \multicolumn{1}{|c|}{ \% of Ni(II) $\boldsymbol{\mu g} / \mathbf{m l}$} & \multirow{2}{*}{ Error (\%) } \\
\cline { 2 - 3 } & Certified & Found & \\
\hline BCS-CRM38T $^{\mathrm{a}}$ & 41.90 & 41.85 & -0.11 \\
\hline Monel 400 $^{\mathrm{b}}$ & 62.15 & 63.02 & +1.38 \\
\hline NTPC ball bearing $^{\mathrm{c}}$ & 10.00 & 9.92 & -0.80 \\
\hline
\end{tabular}

* Average of five determinations

$\%$ Composition

a ), Ni 63.01; C 0.15; S 0.0024; Mn 0.07; Si 0.5; Fe 2.5; Cu 31.0;

b) Ni 41.9; Fe 36.0; Cr 12; Mo 5.83; Ti 2.95; Se 0.28; Al 0.29; Co 0.21; Mn 0.08; Cu 0.092;

c) Fe 65.0; Cr 15.0; $\mathrm{Cu} 4.5 ; \mathrm{Mn} 2.0 ; \mathrm{Ni} 10.00$;

Table -4.

Determination Ni (II) in drinking water

\begin{tabular}{|c|c|c|c|c|c|}
\hline \multirow{3}{*}{$\begin{array}{l}\text { Water } \\
\text { sample }\end{array}$} & \multicolumn{3}{|c|}{ Amount of $\mathrm{Ni}(\mathrm{II}) \mu \mathrm{g} / \mathrm{ml}$} & \multicolumn{2}{|c|}{ Recovery (\%) } \\
\hline & \multirow[t]{2}{*}{ Added } & \multicolumn{2}{|c|}{ Found } & \multirow{2}{*}{$\begin{array}{l}\text { Present } \\
\text { method }\end{array}$} & \multirow[t]{2}{*}{ AAS method } \\
\hline & & Present method & AAS method & & \\
\hline 1 & $\begin{array}{l}- \\
1.00 \\
1.80\end{array}$ & $\begin{array}{l}1.08 \\
2.10 \\
2.86\end{array}$ & $\begin{array}{l}1.07 \\
2.09 \\
2.88\end{array}$ & $\begin{array}{l}- \\
102.0 \\
98.8\end{array}$ & $\begin{array}{l}- \\
102.0 \\
100.5\end{array}$ \\
\hline 2 & $\begin{array}{l}- \\
1.00 \\
1.80 \\
\end{array}$ & $\begin{array}{l}1.80 \\
2.83 \\
3.62 \\
\end{array}$ & $\begin{array}{l}1.81 \\
2.82 \\
3.59 \\
\end{array}$ & $\begin{array}{l}- \\
103.0 \\
101.1\end{array}$ & $\begin{array}{l}- \\
101.0 \\
98.9 \\
\end{array}$ \\
\hline
\end{tabular}

* Average of five determinations

Table -5.

Determination of $\mathrm{Ni}$ (II) of the vegetable oil and leaf samples

\begin{tabular}{|l|c|c|c|}
\hline \multirow{2}{*}{ Sample } & \multicolumn{2}{|c|}{ Amounnt of Ni(II) $(\boldsymbol{\mu g} / \mathbf{m l})$} & \multirow{2}{*}{ Relative error $(\%)$} \\
\cline { 2 - 4 } & Present method* & AAS method & -0.75 \\
\hline Groundnut oil & 0.530 & 0.534 & -1.54 \\
Sunflower oil & 0.650 & 0.660 & -1.23 \\
Eucalyptus leaves & 1.053 & 1.066 & +0.23 \\
Mangifera indica leaves & 2.165 & 2.160 & \\
\hline
\end{tabular}

* Average of five determinations.

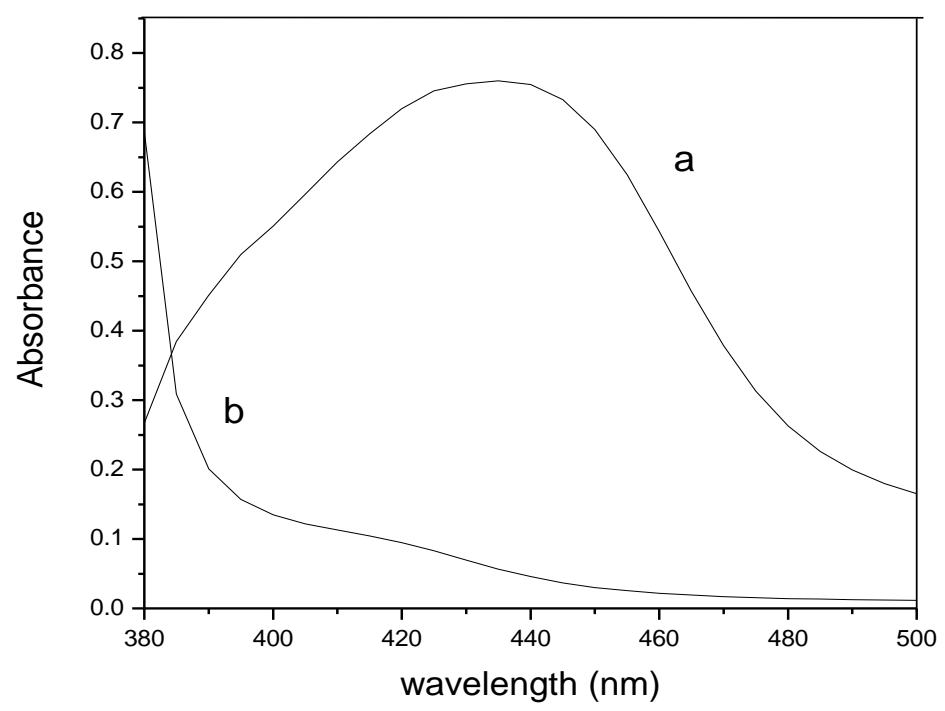

Fig.1. Absorption spectra of

a) 5-BHMBHBH Vs buffer blank

b) $[\mathrm{Ni}$ (II)]-5-BHMBHBH Vs reagent blank

$[\mathrm{Ni}(\mathrm{II})]=3.0 \times 10^{-5} \mathrm{M}$ :

$[5-\mathrm{BHMBHBH}]=1.0 \times 10^{-3} \mathrm{M}$

$\mathrm{pH}=6.0$ 


\section{References:}

[1]. Dixon, N.E., Gazzola, C., Balakey, R.L., and Zerver, B., J.Am. Chem. Soc., (1975),97,4131.

[2]. Hewit, E.J., "Chemistry and Agriculture” Special Publication No. 36 Chem. Society, London, (1971), 91.

[3]. Welch, R.M., J. Plant Nutri., (1981), 3,345.

[4]. Shell F. D., Photometric and Flourometric methods of analysis ,John Wiley, New Yark, (1978)

[5]. Gopala Krishna D., Devanna N., Chandrasekhar K.B., J.Pharm.Biomed .Sci.(2010), 1 ,5.

[6]. Singh R.B.,Jain P, and Singh R.P., Talanta, (1982),29,77.

[7]. Gopala Krishna D, Devanna N., Chandrasekhar K.B., Int.J.Chem Tech Res.(2011), 3 ,(1),506-515

[8]. ArunaBai K, Vallinath G.V.S, Chandrasekhar K.B, Devanna N.,RASĀYAN J.Chem.(2010),3.(3),467-472

[9]. Vishwanatha C, Devanna N., Chandrasekhar K.B.,Int.J.Adv.Phar.Biol.Chem.(2013), 2 (2), 380-384

[10]. Vogel, A. I., A Text book of Quantitative Inorganic Analysis $3^{\text {rd }}$ Ed., ELBS and Longman, (1975). 